\title{
Thrust Characteristics of High-Thrust Spiral Motor Using FEM Analysis
}

\author{
Hyuk-jin Kwon Student Member (Yokohama National University, kwonhj@fujilab.dnj.ynu.ac.jp) \\ Yasutaka Fujimoto Member (Yokohama National University, fujimoto@ynu.ac.jp)
}

Keywords: spiral motor, permeance method, finite-element method, thrust

\section{Thrust Characteristic of Spiral motor}

There are two types of actuators for linear motion. One is a linear motor that has the advantage of not requiring an additional mechanism. The linear motor is free from Coulomb's friction and backlash. However, the flux leakage is larger than that of a rotary motor. A large volume and mass are needed for high thrust output. The other is a combination of a rotary motor and a rotation-tolinear transforming mechanism such as a ball-screw or gears. The

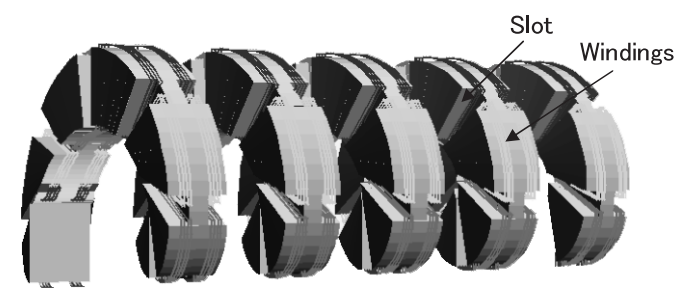

(a) Stator with windings

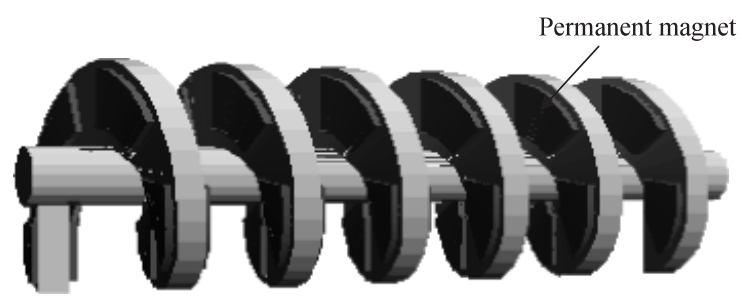

(b) Mover

Fig. 1. Concept of the spiral motor

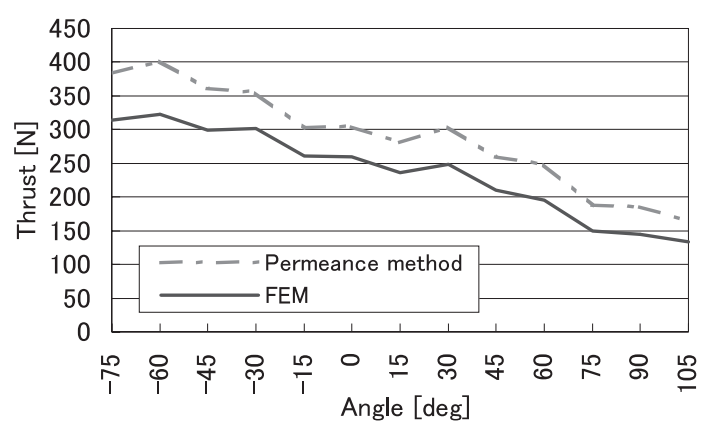

Fig. 2. Motor characteristics of two models depending on $\theta$

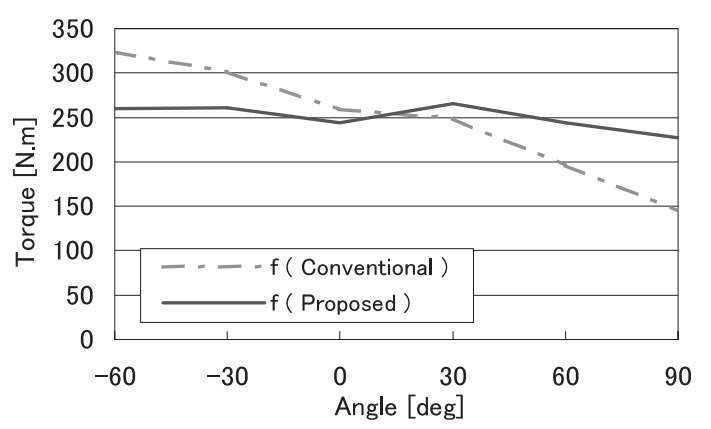

Fig. 3. Compensated thrust depending on rotation angle

additional hardware causes the Coulomb's friction and the backlash that have bad influence on positioning accuracy.

From these facts, we propose a spiral-type motor that has wide gap area, so can have high thrust characteristics. The spiral motor achieves direct-drive motion as well as the linear motors. No additional hardware is needed to convert rotary to linear motion.

Fig. 1 shows the basic concept of the spiral motor. The imposed current on the windings of the stator generates the magnetic flux in axial direction. The spiral motor has two-degree-of-motion- freedom (rotary and linear motion) and can generate both torque and thrust.

The concept of spiral motor is presented in this paper. In order to verify the validity of analysis methods, the permeance method analysis is compared with FEM analysis. Both results are almost same. Fig. 2 shows permeance method and FEM result of thrust of a 5pitch-stator, 6-pitch-mover model. We confirm that this motor has high motor constant as same as High Density Linear Motor (HDL).

\section{Thrust Fluctuation}

We found that this model has thrust fluctuation due to the magnetic attraction between the projected mover and the stator. The fluctuation can be compensated by moving the distance of air gap. Fig. 3 shows the result of compensated thrust depending on rotation angle. We can see that thrust becomes almost constant by controlling of distance of air gap.

\section{Conclusion}

This motor has high thrust characteristics by a structure of wide gap area. This motor is expected to be substituted for traditional drive equipments and various applications. 


\title{
電磁界解析による高推力スパイラルモータの推力特性の検討
}

\author{
学生員 權 赫鎭* 正 員 藤本 康孝** \\ Thrust Characteristics of High-Thrust Spiral Motor Using FEM Analysis \\ Hyuk-jin Kwon*, Student Member, Yasutaka Fujimoto**, Member

\begin{abstract}
We propose a spiral-type motor that has high thrust characteristics as a linear actuator. This motor generates torque around the axis and thrust in the axial direction only by electromagnetic force. It has little friction because no additional hardware is required for straight-line movement. This paper presents the concept of the spiral motor. The finite-element method (FEM) analysis certifies that this motor has high motor constant as same as High Density Linear Motor (HDL). We also study a method to compensate the thrust fluctuation of 5-pitch-stator 6-pitch-mover model
\end{abstract}

キーワード: スパイラルモータ, パーミアンス法, 有限要素法, 推力

Keywords: spiral motor, permeance method, finite-element method, thrust

\section{1. はじめに}

直動アクチュエータは, 産業系に扔いて搬送システムや各 種加工機械などで広く用いられている。直動アクチュエー 夕の動力源としては電気, 油圧, 空気圧があり, 電動直動 アクチュエータは位置, 速度, 力の制御が容易である特徵 があり, 中・小推力が必要な所に用いられている(1)。直線 運動を実現する方法として，主に，リニアモー夕を用いる 方法と, ボールスクリューを用いて回転型モータの運動を 直線運動に変換する方法が用いられている。

リニアモータはモー夕単体で直線運動ができる代表的な 電動直動アクチュエータであるが, 密閉空間の小さな空隙 でエネルギー変換をする回転型モー夕と比較して端部効果 による漏れ磁束が発生するという久点がある。また，高推 力を発生するためは装置が大型になってしまうという問題 がある(2)。

一方，回転型モー夕を用いて推力を得る方法としてはギ ヤやボールスクリューなどの機械装置を外部に付加し回転 運動を直線運動に変換する方式があるが, 装置が複雑にな る, クーロン摩擦の影響により位置決めの精度が低下する, などといった問題がある(3)。

そのほか, 小型高推力でサーボ系の構成が可能な直線運動

\footnotetext{
* 横浜国立大学大学院工学府

于 240-8501 横浜市保土ヶ谷区常盤台 79-5

Graduate school of Engineering, Yokohama National University

79-5, Tokiwadai, Hodogaya-ku, Yokohama 240-8501

** 横浜国立大学大学院工学研究院

干 240-8501 横浜市保土ケ谷区常盤台 79-5

Faculty of Engineering, Yokohama National University

79-5, Tokiwadai, Hodogaya-ku, Yokohama 240-8501
}

アクチュエータとしてDDVC (Direct Drive Volume Control）方式による油圧アクチュエータがある。この方法は サーボモータと油圧ポンプを軸直結した構造で作動油の漏 れが少なく, 一般油圧アクチュエータより高効率である(4)(5)。 しかし, 動力伝達の媒体として油圧が使われるため電気工 ネルギーから直接駆動するモー夕よりは低効率であると考 えられる。

そこで, 著者らは電磁力のみによって大きな推力が期待 できるスパイラル型モータを考案する。スパイラルモータ は可動子, 固定子がスパイラル型の構造を持つことによっ て可動子がスパイラル運動をするモータである。本モー夕 は磁束を 3 次元的に有効に利用し, かつ, ギャップ面積を大 きく取れるため小型で高推力が得られる。リニアモータと 同様に機械的変換装置が必要なくモー夕単体で前後進運動 ができ,クーロン摩擦による損失がほとんどないため, 高 精度の位置決めが可能となることが期待される。

単体でスパイラル運動が可能なアクチュエータとしては 回転ーリニアモー夕（Rotary-Linear Motor：RLM）が提案 されている(6)。これは複数の鉄心を円周上に並べた形状の リニアモータで, 卷線の電源位相差による回転運動と直線 運動の合成でスパイラル運動ができる。このモータと比較 してスパイラルモー夕は可動子と固定子が構造的にかみ合 うためギャップの面積が大きく, RLM より高推力が可能で あると考えられる。

本論文ではスパイラルモータの概念提案と理論的考察を 行う。パーミアンス法による解析から推力拉よびトルクの 式を導出し, 有限要素法 (Finite-element Method:FEM)に よる電磁界解析での推力值との比較を行い考察する。その 結果, モー夕定数が大きいことで知られている HD リニア 
モータ (HDL) (7) と同等な性能を発揮することを確認する。 さらに,このモータの構造の特性上, 発生推力が可動子の 突出量に比例して増減するため, ギャップ変位の移動によ る推力平坦化について考察する。

\section{2. スパイラルモータの構造と推力発生の原理}

〈2·1〉 スパイラルモータの構造スパイラルモータ の概念を図 1 に示す。可動子, 固定子共にらせん形状で, 可動子は固定子のピッチ間でらせん方向に回転しながら前 後進する。

固定子と可動子の軸方向投影図を図 2 に示す。固定子の 表面と裏面（各々領域 $(A)$, 領域 $(B)$ と呼ぶ）に 3 相巻線を 施し，軸方向に回転磁界を発生させる。可動子には軸方向 に起磁力を持つ永久磁石が両面に接着されている。図 3 は

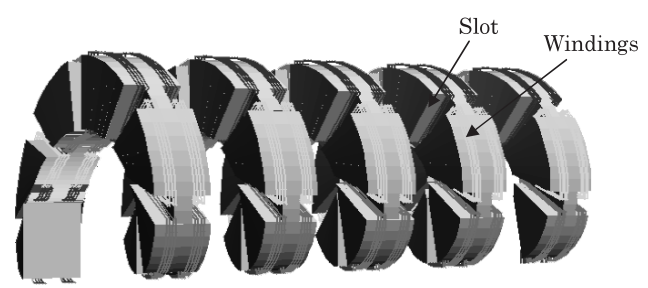

(a) Stator with windings

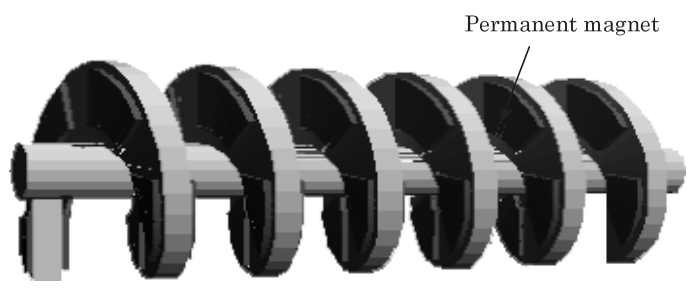

(b) Mover

図 1 スパイラルモータの概念

Fig. 1. Concept of spiral motor.

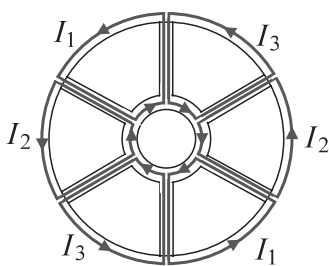

(a) Stator

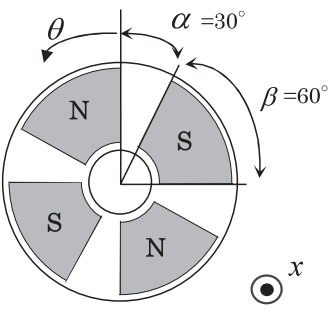

(b) Mover
図 2 固定子と可動子の軸方向投影図

Fig. 2. Axial projection of stator and mover.

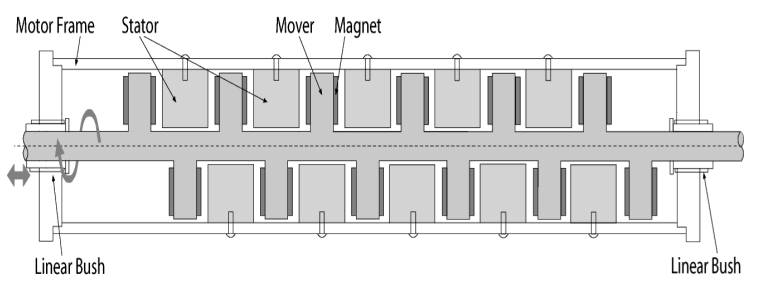

図 3 スパイラルモータの構造

Fig. 3. Structure of spiral motor.
スパイラルモータの縦断面図である。スパイラルモータで は主に軸方向に磁束を発生させる構造となっている。これ はアキシャル型磁気浮上モータと類似した構造であるとい える ${ }^{(8)}$ 。可動子はモータフレーム両端において回転と直線 運動が可能なリニアブッシュにより支持される。半径方向 負荷はリニアブッシュにより支持され，軸方向の負荷は電 磁力の適切な制御により支えられる。すなわち, 可動子の 永久磁石と固定子鉄心間には吸引力が作用するため, 固定 子鉄心間の平衡点近傍で固定子-可動子間ギャップ変位の 制御が必要となる。可動子の軸方向変位および回転角を測 定するため可動子にリニアエンコーダおよびロータリエン コーダを取り付ける。

〈2·2〉推力発生の原理図 4 は極座標系で展開した スパイラルモータであり, 図 5 は極座標展開図から導き出 した等価磁気回路である。このモデルは可動子の回転角が $0^{\circ} \leq \theta \leq 30^{\circ}$ のとき 3 相分の簡易モデルになっており，本 モー夕のモー夕特性を考察しやすくするため次の仮定上で 作成された。

[仮定 1]

(1) 固定子と可動子の鉄心の磁気抵抗を無視

(2) 漏れパーミアンスを無視

(3) 端部の影響を無視（無限長モデルと同じ磁束分布）

(4) スロット部の領域を無視

このモデルを用いて本モータの推力発生の原理を明らかにす る。磁気回路の各パラメー夕を表 1 に示す。ただし, ギャッ プ変位 $x_{g}$ は軸方向位置 $x$ と回転角 $\theta$ を用いて (1) 式のよう に表される。

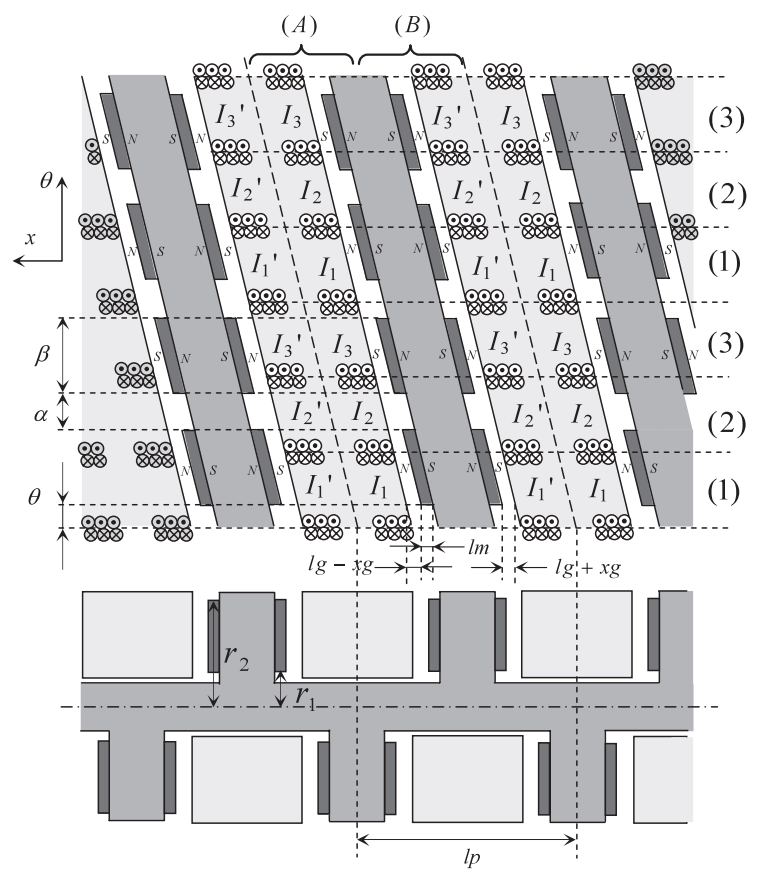

図 4 極座標展開図

Fig. 4. Spiral motor in polar coordinates. 


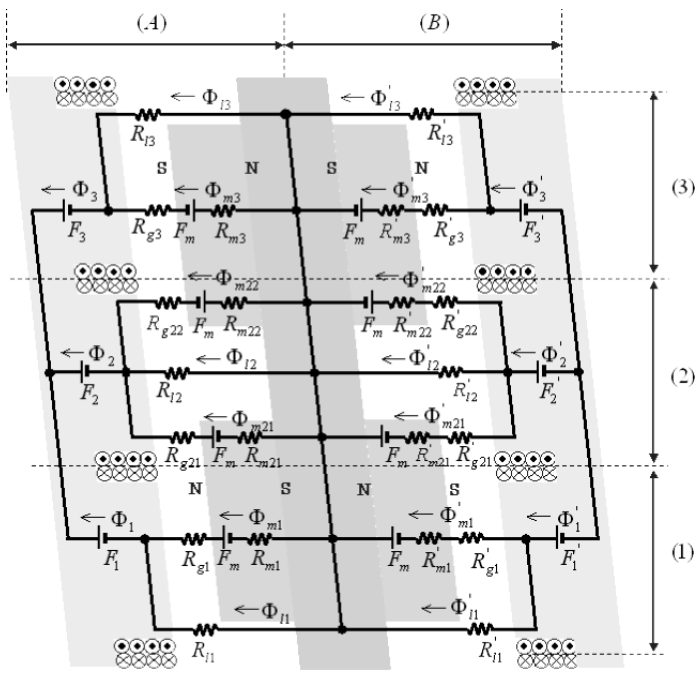

図 5 簡易モデルの等価磁気回路 $\left(0^{\circ} \leq \theta \leq 30^{\circ}\right)$

Fig. 5. Equivalent magnetic circuit of simplified model $\left(0^{\circ} \leq \theta \leq 30^{\circ}\right)$.

表 1 各パラメータ

Table 1. Parameters.

\begin{tabular}{c|l}
\hline$I_{1}, I_{2}, I_{3}$, & Three-phase field current in domain $(\mathrm{A})$, \\
$I_{1}^{\prime}, I_{2}^{\prime}, I_{3}^{\prime}$ & (B) [A] \\
$n$ & Number of turns of windings \\
$x_{g}$ & Displacement of air gap [m] \\
$x$ & Linear position of mover [m] \\
$\theta$ & Rotation angle of mover [rad] \\
$p$ & Number of pole pairs \\
$q$ & Number of pitch \\
$\alpha$ & Angle between two adjacent magnets [rad] \\
$\beta$ & Angle of magnet [rad] \\
$B_{r}$ & Residual magnetic flux density [T] \\
$\mu_{0}$ & Magnetic permeability of vacuum \\
$\mu_{m}$ & Magnetic permeability of magnet \\
$l_{m}$ & Thickness of magnet [m] \\
$l_{g}$ & Nominal displacement of air gap $[\mathrm{m}]$ \\
$l_{p}$ & Length of pitch [m] \\
$r_{1}, r_{2}$ & Inner and outer radius of magnet $[\mathrm{m}]$ \\
\hline
\end{tabular}

$$
x_{g}=x-\frac{l_{p}}{2 \pi} \theta
$$

各領域を通る磁束は磁気回路方程式から求められる。 $i=1$, 2，3 として図 5 の領域 $(A),(B)$ について， $(A)-(i)$ の領域 での巻線による起磁力を $F_{i}$, 永久磁石による起磁力を $F_{m}$, ギャップと永久磁石と漏れ磁路の磁気抵抗をそれぞれ $R_{g j}$ $(j=1,21,22,3), R_{m j}(j=1,21,22,3), R_{l i}(i=1,2$, 3）とすると, これらは永久磁石の残留磁束密度, 透磁率, 媒体の長さ，面積を用いて (2)〜 (6) 式のように表される。

$$
\begin{aligned}
& F_{i}=n I_{i} \cdots \\
& F_{m}=\frac{B_{r} l_{m}}{\mu_{m}}
\end{aligned}
$$

$$
\begin{aligned}
R_{g j} & =\frac{l_{g}-x_{g}}{a_{j} S_{0} \mu_{0}} \\
R_{m j} & =\frac{l_{m}}{a_{j} S_{0} \mu_{m}} \\
R_{l i} & =\frac{l-x_{g}}{b_{i} S_{0} \mu_{0}}
\end{aligned}
$$

ただし, $S_{0}=\left(r_{2}^{2}-r_{1}^{2}\right) / 2, a_{1}=2 \alpha-\theta, a_{21}=\theta, a_{22}=\alpha-\theta$, $a_{3}=\alpha+\theta, \quad b_{1}=\theta, \quad b_{2}=\alpha, \quad b_{3}=\alpha-\theta, l=l_{m}+l_{g}$ であ る。図 5 より磁気回路方程式は次のように求まる。

$$
\begin{aligned}
& R_{l 1} \Phi_{l 1}=-F_{m}+\left(R_{m 1}+R_{g 1}\right) \Phi_{m 1} \ldots \ldots \ldots \ldots \\
& R_{l 2} \Phi_{l 2}=-F_{m}+\left(R_{m 21}+R_{g 21}\right) \Phi_{m 21} \\
&=F_{m}+\left(R_{m 22}+R_{g 22}\right) \Phi_{m 22} \ldots \ldots \ldots \ldots \\
& R_{l 3} \Phi_{l 3}=F_{m}+\left(R_{m 3}+R_{g 3}\right) \Phi_{m 3} \ldots \ldots \ldots \ldots \ldots \\
& \Phi_{1}+\Phi_{2}+\Phi_{3}=0 \ldots \ldots \ldots \ldots \ldots \ldots \\
&-F_{1}+R_{l 1} \Phi_{l 1}=-F_{2}+R_{l 2} \Phi_{l 2}=-F_{3}+R_{l 3} \Phi_{l 3}
\end{aligned}
$$

ただし, $\Phi_{i}(i=1,2,3)$ は領域 $(i)$ の磁束を表し, $\Phi_{1}=$ $\Phi_{l 1}+\Phi_{m 1}, \Phi_{2}=\Phi_{l 2}+\Phi_{m 21}+\Phi_{m 22}, \Phi_{3}=\Phi_{l 3}+\Phi_{m 3}$ であ る。(2)〜(6) 式で求めたパラメータを (7) （11) 式に代入し て, 3 相平衡入力電流条件と $\mu_{0}=\mu_{m}$ の条件で各領域の磁 束を求めると, 以下の様になる。

$$
\Phi_{i}=\frac{S_{0} \mu_{0}}{l-x_{g}}\left(c_{i} F_{m}+2 \alpha n I_{i}\right) \quad(i=1,2,3) .
$$

ただし $, c_{1}=2 \alpha-\theta, c_{2}=-\alpha+2 \theta, c_{3}=-\alpha-\theta$ である。 同様に領域 $(B)$ の磁束も求められる。

$$
\Phi_{i}^{\prime}=\frac{S_{0} \mu_{0}}{l+x_{g}}\left(c_{i} F_{m}+2 \alpha n I_{i}^{\prime}\right) \quad(i=1,2,3)
$$

ところで, 領域 $(A)-(i)$ の磁気抵抗を $R_{i}$, 領域 $(B)-(i)$ の磁 気抵抗を $R_{i}^{\prime}$ とすると

$$
\begin{aligned}
& R_{1}=\frac{R_{l 1}\left(R_{m 1}+R_{g 1}\right)}{R_{l 1}+R_{m 1}+R_{g 1}}, \quad R_{3}=\frac{R_{l 3}\left(R_{m 3}+R_{g 3}\right)}{R_{l 3}+R_{m 3}+R_{g 3}}, \\
& R_{2}=\frac{R_{l 2}\left(R_{m 21}+R_{g 21}\right)\left(R_{m 22}+R_{g 22}\right)}{R_{l 2}\left(R_{m 21}+R_{g 21}\right)+R_{l 2}\left(R_{m 22}+R_{g 22}\right)+\left(R_{m 21}+R_{g 21}\right)\left(R_{m 22}+R_{g 22}\right)}, \\
& R_{1}^{\prime}=\frac{R_{l 1}^{\prime}\left(R_{m 1}^{\prime}+R_{g 1}^{\prime}\right)}{R_{l 1}^{\prime}+R_{m 1}^{\prime}+R_{g 1}^{\prime}}, \quad R_{3}^{\prime}=\frac{R_{l 3}^{\prime}\left(R_{m 3}^{\prime}+R_{g 3}^{\prime}\right)}{R_{l 3}^{\prime}+R_{m 3}^{\prime}+R_{g 3}^{\prime}}, \\
& R_{2}^{\prime}=\frac{R_{l 2}^{\prime}\left(R_{m 21}^{\prime}+R_{g 21}^{\prime}\right)\left(R_{m 22}^{\prime}+R_{g 22}^{\prime}\right)}{R_{l 2}^{\prime}\left(R_{m 21}^{\prime}+R_{g 21}^{\prime}\right)+R_{l 2}^{\prime}\left(R_{m 22}^{\prime}+R_{g 22}^{\prime}\right)+\left(R_{m 21}^{\prime}+R_{g 21}^{\prime}\right)\left(R_{m 22}^{\prime}+R_{g 22}^{\prime}\right)}
\end{aligned}
$$

であり，(4) (6) 式を代入し $\mu_{m}=\mu_{0}$ とすると $R_{1}, R_{2}$, $R_{3}$ および $R_{1}^{\prime}, R_{2}^{\prime}, R_{3}^{\prime}$ は等しくなり, 以下の様になる。

$$
\begin{aligned}
R_{i} & =\frac{l-x_{g}}{2 \alpha \mu_{0} S_{0}} \quad(i=1,2,3) \\
R_{i}^{\prime} & =\frac{l+x_{g}}{2 \alpha \mu_{0} S_{0}} \quad(i=1,2,3)
\end{aligned}
$$

このとき, $\Phi_{1}, \Phi_{2}, \Phi_{3}$ および $\Phi_{1}^{\prime}, \Phi_{2}^{\prime}, \Phi_{3}^{\prime}$ は (10) 式の 3 相平衡条件を満たすことが分かる。

(12), (13) 式の磁束より領域 $(A)$ と $(B)$ の磁気エネルギー 
を求め, その和を変位 $x$ および回転角 $\theta$ で偏微分すると推 力とトルクが求まる。(16), (17) 式は領域 $(A)$ と $(B)$ 側の 磁気エネルギーを，(18), (19) 式は全体の推力とトルクを 表す。

$$
\begin{aligned}
W_{0} & =p q \frac{n I_{1} \Phi_{1}+n I_{2} \Phi_{2}+n I_{3} \Phi_{3}+F_{m} \Phi_{m}}{2} \\
& =\frac{p q \mu_{0} S_{0}}{l-x_{g}}\left(2 \alpha F_{m}^{2}+n F_{m} \sum_{i=1}^{3} c_{i} I_{i}+\alpha n^{2}|I|^{2}\right) \\
\ldots \ldots \ldots \ldots \ldots \ldots \ldots & \\
W_{0}^{\prime} & =p q \frac{n I_{1}^{\prime} \Phi_{1}^{\prime}+n I_{2}^{\prime} \Phi_{2}^{\prime}+n I_{3}^{\prime} \Phi_{3}^{\prime}+F_{m} \Phi_{m}^{\prime}}{2} \\
& =\frac{p q \mu_{0} S_{0}}{l+x_{g}}\left(2 \alpha F_{m}^{2}+n F_{m} \sum_{i=1}^{3} c_{i} I_{i}+\alpha n^{2}\left|I^{\prime}\right|^{2}\right)
\end{aligned}
$$

ただし， $\Phi_{m}=\Phi_{m 1}+\Phi_{m 21}-\Phi_{m 22}-\Phi_{m 3},|I|^{2}=\sum_{i=1}^{3} I_{i}^{2}$, $\Phi_{m}^{\prime}=\Phi_{m 1}^{\prime}+\Phi_{m 21}^{\prime}-\Phi_{m 22}^{\prime}-\Phi_{m 3}^{\prime},\left|I^{\prime}\right|^{2}=\sum_{i=1}^{3} I_{i}^{\prime 2}$ である。

$$
\begin{aligned}
f= & \frac{\partial W}{\partial x} \\
= & p q S_{0} \mu_{0}\left(\frac{n F_{m} \sum_{i=1}^{3} c_{i} I_{i}}{\left(l-x_{g}\right)^{2}}+\frac{n^{2} \alpha|I|^{2}}{\left(l-x_{g}\right)^{2}}-\frac{n F_{m} \sum_{i=1}^{3} c_{i} I_{i}^{\prime}}{\left(l+x_{g}\right)^{2}}\right. \\
& \left.\quad-\frac{n^{2} \alpha\left|I^{\prime}\right|^{2}}{\left(l+x_{g}\right)^{2}}+\frac{8 \alpha F_{m}^{2} x_{g} l}{\left(l^{2}-x_{g}^{2}\right)^{2}}\right) \cdots \cdots(18) \\
\tau & =\frac{\partial W}{\partial \theta} \\
= & p q n \mu_{0} F_{m} S_{0}\left(\frac{-I_{1}+2 I_{2}-I_{3}}{l-x_{g}}+\frac{-I_{1}^{\prime}+2 I_{2}^{\prime}-I_{3}^{\prime}}{l+x_{g}}\right)-\frac{l_{p}}{2 \pi} f
\end{aligned}
$$

ただし， $W=W_{0}+W_{0}^{\prime}$ である。推力の (18) 式で括弧内第 1 項と第 3 項は領域 $(A)$ と $(B)$ の 3 相電流と永久磁石間の ローレンツカ, 第 2 項と第 4 項は領域 $(A)$ と $(B)$ の固定子巻 線の磁束と可動子鉄心間の吸引力, 第 5 項は永久磁石と固 定子鋼板間の吸引力を意味する。トルクの (19) 式で括弧内 第 1 項と第 2 項は領域 $(A)$ と $(B)$ の 3 相電流と永久磁石間 のローレンツカに起因するトルクを意味する。本モータは スパイラル型であるため推力の $l_{p} / 2 \pi$ 分がトルクに換算さ れる。推力とトルクにおける各相の係数は 3 相平衡になっ ている。

上式の入力電流項をみると， $x_{g}=0$ のとき固定子の領域 $(A)$ の巻線 3 相分と領域 $(B)$ の 3 相分の值がそれぞれと一 致すると推力が 0 ，トルクが最大となることが分かる。一 方, 領域 $(A)$ の 3 相分が領域 $(B)$ の 3 相分と逆符号の值を 持つ場合は推力が最大になる。このことから，入力電流の 制御によって推力とトルクを調節し，スパイラル運動の制 御が可能であることが分かる。また，領域 $(A)$ の 3 相電流 と領域 $(B)$ の 3 相電流を独立に制御する必要があるため 3 相の電源が 2 セット必要になる。

\section{3. 解析モデルの妥当性の検証}

これまでにない特殊な構造のスパイラルモータの推力特

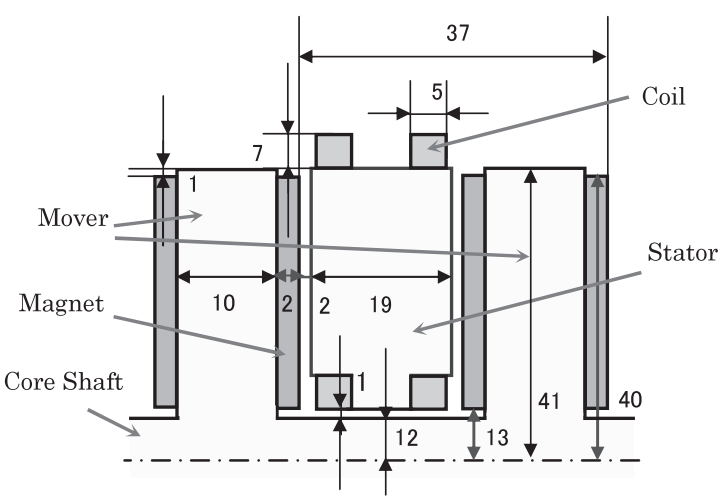

困 6 スパイラルモータの寸法 (単位：mm)

Fig. 6. Dimensions of spiral motor (unit: $\mathrm{mm}$ ).

表 2 モデルの仕様

Table 2. Specifications of model.

\begin{tabular}{cl|r}
\hline$l_{g}$ & Nominal displacement of air gap & $0.002[\mathrm{~m}]$ \\
$l_{m}$ & Length of pitch & $0.002[\mathrm{~m}]$ \\
$\alpha$ & Angle between two adjacent magnets & $\pi / 6[\mathrm{rad}]$ \\
$\beta$ & Angle of magnet & $\pi / 3[\mathrm{rad}]$ \\
$r_{1}$ & Inner radius of magnet & $0.013[\mathrm{~m}]$ \\
$r_{2}$ & Outer radius of magnet & $0.04[\mathrm{~m}]$ \\
$B_{r}$ & Residual magnetic flux density & $1.3[\mathrm{~T}]$ \\
$\mu_{0}$ & Magnetic permeability of vacuum & $4 \pi \times 10^{-7}$ \\
$\mu_{m}$ & Magnetic permeability of magnet & $4 \pi \times 10^{-7}$ \\
$n$ & Number of turns of windings & 20 \\
$p$ & Number of pole pairs & 2 \\
$q$ & Number of pitch & 6 \\
\hline
\end{tabular}

性を検討するにあたり，パーミアンス法による解析だけで は精度が十分でないと考えられるので，同一の条件，モデ ルで FEM 解析を行い, 両解析モデルを比較した。図 6 と 表 2 にモデルの寸法とパラメータの詳細を示す。

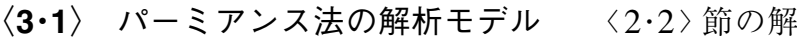
析モデルは[仮定 1]のもと理想化した等価磁気回路に基づ いている。本節では FEM 解析と同じ条件で比較するため, [仮定 1]の(4)を除いて，スロットを考慮した条件の解析モ デルを適用した。

[仮定 2]

(1) 固定子と可動子の鉄心の磁気抵抗を無視

(2) 漏れパーミアンスを無視

(3) 端部の影響を無視（無限長モデルと同じ磁束分布） スロット部には磁路が存在しないと仮定したモデルの等価 磁気回路を考え, 図 7 にそのモデルを表す。各領域の磁束は 図 7 の右端に表示された領域に分けられる。それぞれの角度 は $\gamma_{l 1}=\left(\theta-\frac{1}{6} \alpha\right), \gamma_{l 2}=\alpha, \gamma_{l 3}=\left(-\theta+\frac{5}{6} \alpha\right), \gamma_{m 1}=\left(-\theta+\frac{11}{6} \alpha\right)$, $\gamma_{m 21}=\left(\theta-\frac{1}{6} \alpha\right), \gamma_{m 22}=\left(-\theta+\frac{5}{6} \alpha\right), \gamma_{m 3}=\left(\theta+\frac{5}{6} \alpha\right), \gamma_{s l o t}=\frac{1}{6} \alpha$ である。

図 8 にこのモデルを用い, 表 2 のパラメータを適用して 計算した領域 $(A)$ の各相電流の推力定数を示す。結果は正 


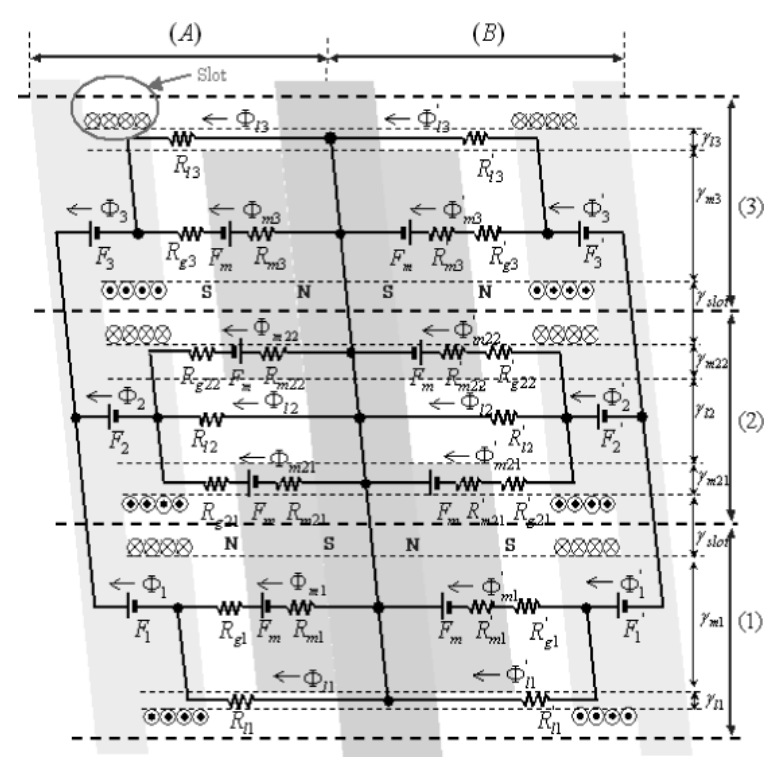

図 7 スロット付きモデルの等価磁気回路 $\left(0^{\circ} \leq \theta \leq 30^{\circ}\right)$

Fig.7. Equivalent magnetic circuit of slotted type model $\left(0^{\circ} \leq \theta \leq 30^{\circ}\right)$.

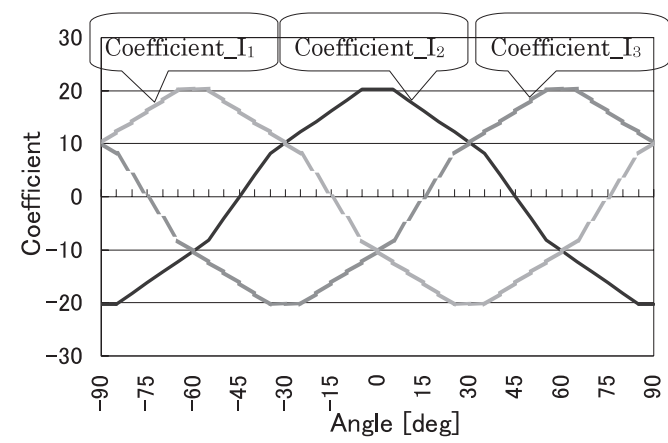

図 8 スロット付きモデルの $I_{1}, I_{2}, I_{3}$ 項の推力定数

Fig. 8. Thrust constant of $I_{1}, I_{2}, I_{3}$ of slotted type model.

弦波に近いし，各相の推力定数が 3 相平衡になっているこ とが分かる。

〈3·2〉 FEM 解析モデル 図 9 に 11 層固定子と 6 層 可動子の FEM モデルを示す。ただし， 1 層はらせんの 1 ピッチ分を表わす。〈3・1 節のパーミアンス法による解析 では無限の固定子層数を持つモデルを仮定して磁束分布を 求めており，これと同じ解析条件で解析するため，FEM モ デルの固定子の層数を可動子の層数より多くした。FEM モ デルの総要素数は空気層を含んで約 38 万個である。

実機モデルと FEM モデルのスロット部寸法は図 10 に 示す。試作機では固定子の外縁部から中心部にわたり均一 に $69.6\left[\mathrm{~mm}^{2}\right]$ の断面積のスロットを施すことを想定する。 線心の線径を $\phi 1.15[\mathrm{~mm}]$ (断面積 $1.04\left[\mathrm{~mm}^{2}\right]$ ), 占積率を $60 \%$ とした場合，1 スロットには 40 本の線心が入る。エナ メル銅線の許容温度を $125^{\circ} \mathrm{C}$ とすると ${ }^{(9)}$ ，この単心線の断

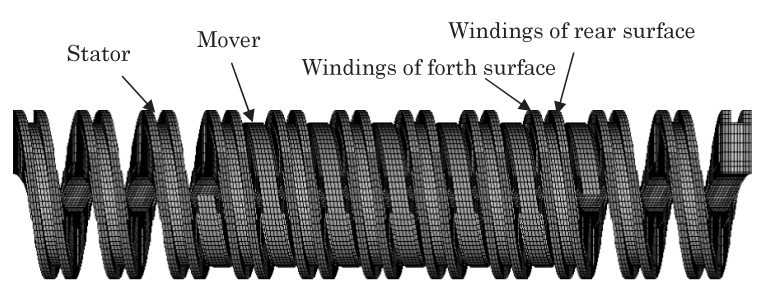

図 911 層固定子スパイラルモータの FEM モデル （空気層は省略）

Fig. 9. FEM model of 11 pitch-stator spiral motor (air omitted).

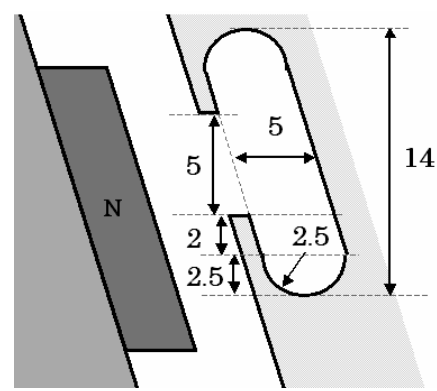

(a) Prototype model

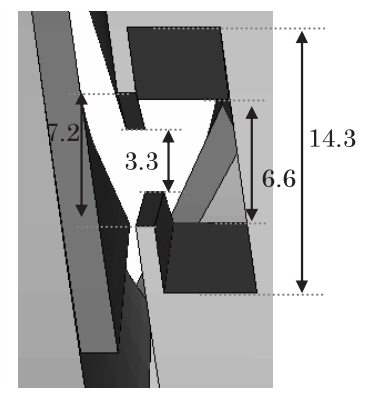

(b) FEM model
図 10 実機モデルと FEM モデルのスロット部寸法

Fig. 10. Dimension of slot of prototype and FEM model.

面積に相当する銅線の許容電流は 17 [A] であり, 複数線に よる減少係数 0.26 と温度補正係数 1 を乗じ, 断面積で割 ると, 1 巻線に流れる許容電流密度は $4.3\left[\mathrm{~A}_{\mathrm{rms}} / \mathrm{mm}^{2}\right]$ にな る ${ }^{(10)(11)}$ 。FEM の熱解析を行ったところ巻線温度が $125\left[{ }^{\circ} \mathrm{C}\right]$ となる電流值は $3.9\left[\mathrm{~A}_{\mathrm{rms}}\right]$ であった。許容電流密度は冷却 フィンの導入や熱伝導路を工夫することにより高めること ができると考えられる。なお, FEM モデルのスロット部 においてはモデリングの制限によってモータ中心部の幅が 狭く, 外縁部は広くなる設定になっており, 許容電流は実 機モデルの場合より若干低くなると考えられる。今回のシ ミュレーションでは電流のピーク值を許容電流密度以下の $3.5\left[\mathrm{~A}_{\mathrm{rms}}\right]$ (ピーク電流 $5[\mathrm{~A}]$ ) とし, 定格出力を発生させる ための電流（定格電流）とした。シミュレーションのため の条件は次のようになる。

[仮定 3]

(1) 固定子と可動子の鉄心は線形材料である 可動子の電気角に同期した最大 5 [A] の 3 相正弦波電流を領 域 $(A)$ と $(B)$ の巻線に逆符号で入力し, 可動子を $15^{\circ} \sim 105^{\circ}$ の間で $30^{\circ}$ づつ回転させながら各回転角で推力とトルクを 求めた。今回の全ての FEM 解析ではシミュレーションの制 限で静解析のみを行った。図 11 にく3・1〉節のモデルの推力 とトルクのパーミアンス法による解析と FEM 解析の結果を 表す。推力はパーミアンス法による解析值が平均 337 [N], FEM 解析值が平均 322 [N] となり両者がほぼ一致した。ト 


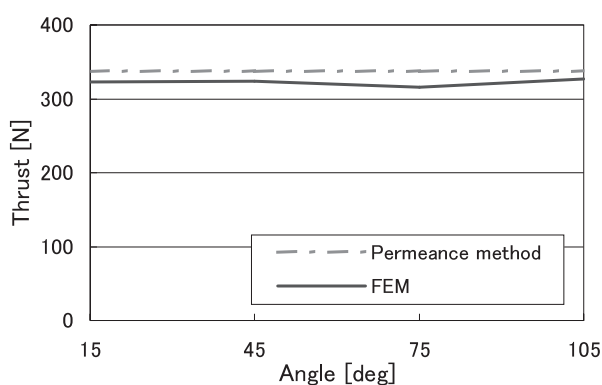

(a) Thrust at 5 [A]

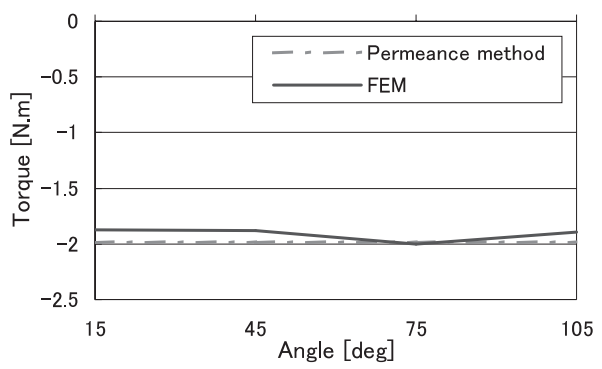

(b) Torque at $5[\mathrm{~A}]$

図 11 各回転角でのモー夕特性のパーミアンス法 による解析值と FEM 解析值

Fig. 11. Motor characteristics of permeance method and FEM analysis depending on $\theta$.

ルクもパーミアンス法による解析值が平均 1.99 [N.m], FEM 解析值が平均 1.88 [N.m] で, ほぼ一致し, 両者の解析が妥 当性を持つことが分かる。

\section{4. 実機モデルの推力特性検討}

実機モデルは推力/体積比を可能な限り大きくとるために ストロークを短く，固定子と可動子の層数差を小さくした。 本章では， $\phi 134[\mathrm{~mm}] \times 355[\mathrm{~mm}]$ サイズの 5 層固定子， 6 層可動子の実機モデルを考え，その推力特性を検討する。

〈4・1〉 解析条件 パーミアンス法による解析では両 端からの影響を考慮し，[仮定 2]の(3)を除いた条件を適用 した。

[仮定 4]

(1) 固定子と可動子の鉄心の磁気抵抗を無視

(2) 漏れパーミアンスを無視

図 12 は可動子が $\theta=-75^{\circ}$ における詳細モデルの等価磁気 回路である。

図 13 は FEM モデルを示す。空気層を含んだ全体のモデ ルの総要素数は約 27 万個である。実機に近いモデルを解 析するため，仮定条件は次のようになる。

[仮定 5]

(1) 固定子の鉄心は飽和磁化特性を持つ

固定子の材料は約 1.8 [T] で磁束飽和し, 円筒座標系で 94\%の 占積率を持つ電磁鋼板である。シミュレーションでは平衡 角 $\theta=15^{\circ}$ を中として, 可動子を $-75^{\circ} \sim 105^{\circ}$ の間で $15^{\circ}$ づつ回転させて各回転角で推力とトルクを求めた。

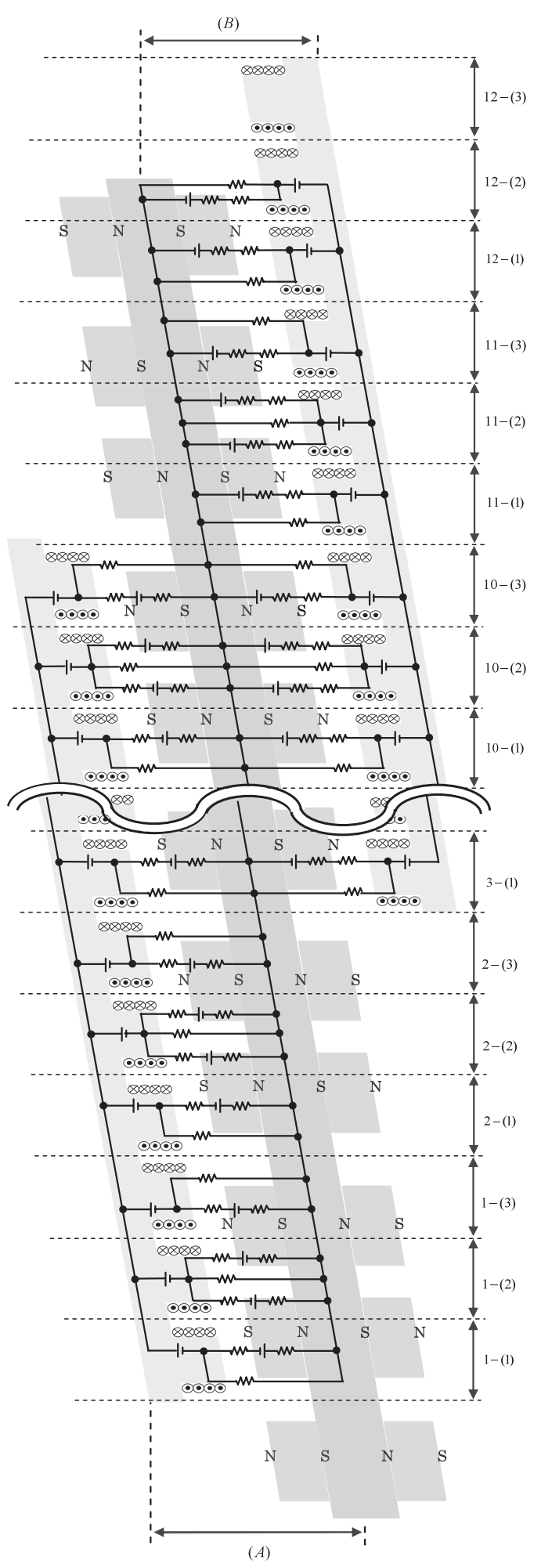

図 $12 \theta=-75^{\circ}$ における詳細モデルの等価磁気回路

Fig. 12. Equivalent magnet circuit of precise model at $\theta=-75^{\circ}$.

〈4・2〉解析結果 図 14 に回転角 $\theta=15^{\circ}$ での固定 子と可動子鉄心部の磁束密度分布を示す。可動子の磁石部 とスロットのティース部が重なる部分に磁束分布が高まっ ていることが分かる。図 15 に固定子と可動子の間，空気 ギャップ部の磁束密度分布を示す。ほとんどの部位におい 


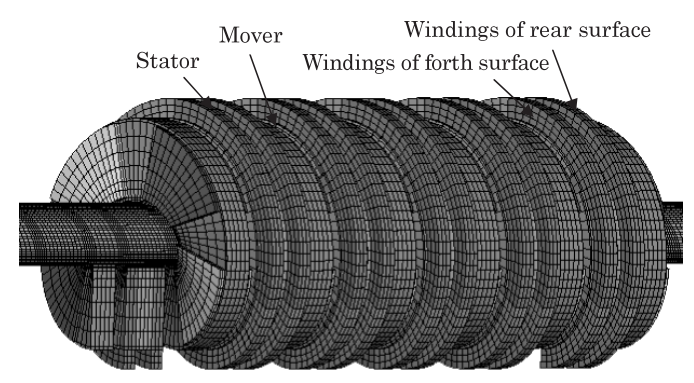

図 135 層固定子スパイラルモータの FEM モデル

Fig. 13. FEM model of 5-pitch-stator spiral motor.

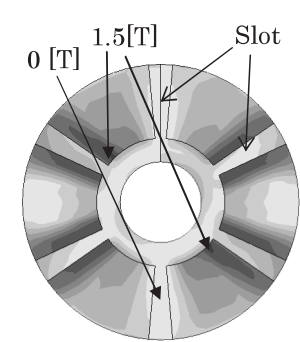

(a) Stator

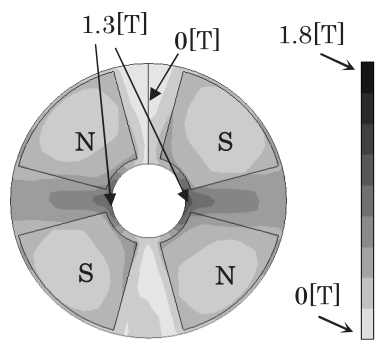

(b) Mover
図 14 固定子と可動子の磁束密度

Fig. 14. Flux density of stator and mover.

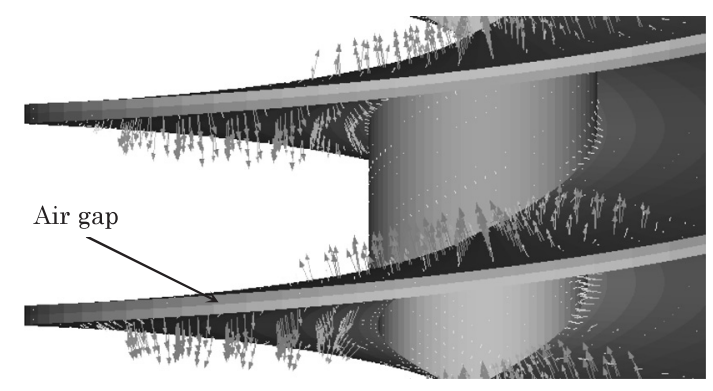

図 15 ギャップ部分の磁束の方向

Fig. 15. Direction of flux at air gap.

て磁束の方向は固定子と可動子の面に垂直となっており, 磁束が 3 次元的に利用されていることが分かる。

図 16 に[A] の電流入力のときの推力とトルクのパーミ アンス法による解析と FEM 解析結果を示す。FEM 解析結 果は $236[\mathrm{~N}]$ である。両解析結果の差は, 鋼板の磁気抵抗 と磁気飽和，および，スロットティース部の考慮の有無に よる結果であると考えられる。

$\langle\mathbf{4} \cdot \mathbf{3}\rangle$ 推力特性に対する考察両解析の推力は回転角 $\theta$ に依存して増減する傾向を見せている。図 17(a)に0[A] の入力電流での推力を示す。これは固定子-可動子間永久 磁石による吸引力を意味する。この吸引力も同じく $\theta$ に依 存して増減することから推力の角度依存性は永久磁石の吸 引力から影響を受けていることが分かる。可動子が正方向 に進行すると可動子の前側だけが突出する形となり，吸引 力が $(-)$ に働く。また, 可動子が負方向に進行すると後側 だけが突出する形となり，(+)の吸引力が働く。

図 17(b) は可動子の回転角において領域 $(A)$ の永久磁石の

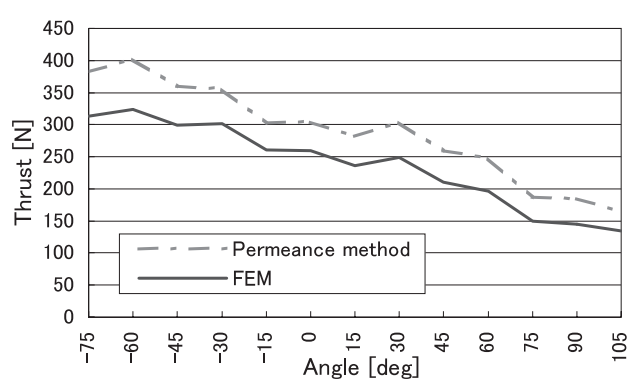

(a) Thrust at 5 [A]

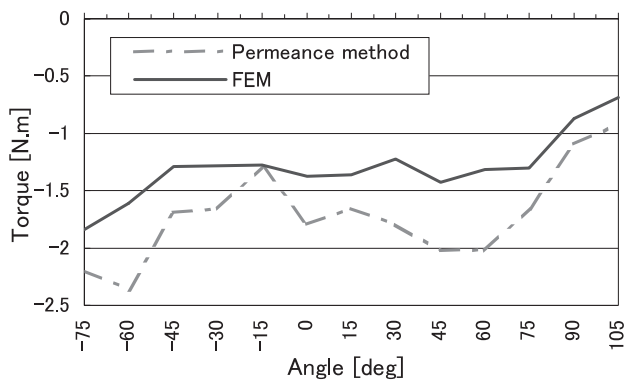

(b) Torque at $5[\mathrm{~A}]$

図 16 各回転角でのモー夕特性の解析值

Fig. 16. Motor characteristics of model depending on $\theta$.

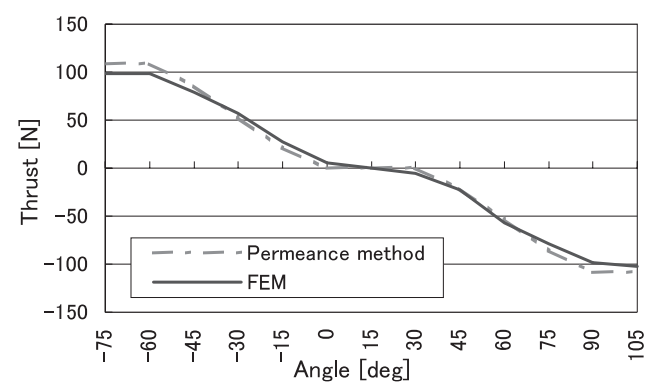

(a) Thrust at $0[\mathrm{~A}]$

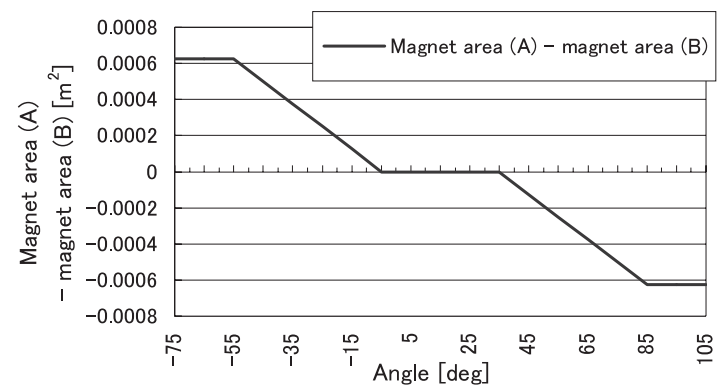

(b) Subtraction of gap area of magnets of (A) from (B)

図 $170[\mathrm{~A}]$ での推力と磁石のギャップ部分面積の差

Fig. 17. Thrust at $0[\mathrm{~A}]$ and subtraction of gap area of magnets.

ギャップ面積から領域 $(B)$ の永久磁石ギャップ面積を差し引 いた面積を表す。面積の差は $\theta$ に依存して増減し, 困 17(a), (b) ともに $-75^{\circ} \sim-55,-5^{\circ} \sim 35^{\circ}, 85^{\circ} \sim 105^{\circ}$ の範囲では 平坦になっている。この結果から可動子に永久磁石がない 角度領域では磁石のギャップ面積の変化がないため推力が 平坦になることが分かる。

つぎに，可動子の移動による 3 相不平衡について考察す 


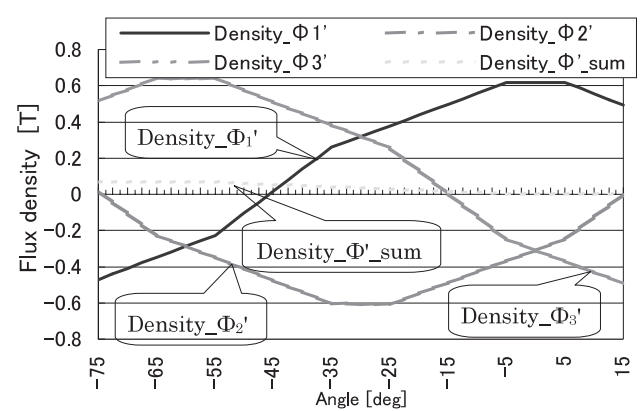

(a) Flux density of non-edge part at domain $(B)\left(-75^{\circ} \leq \theta \leq 15^{\circ}\right)$

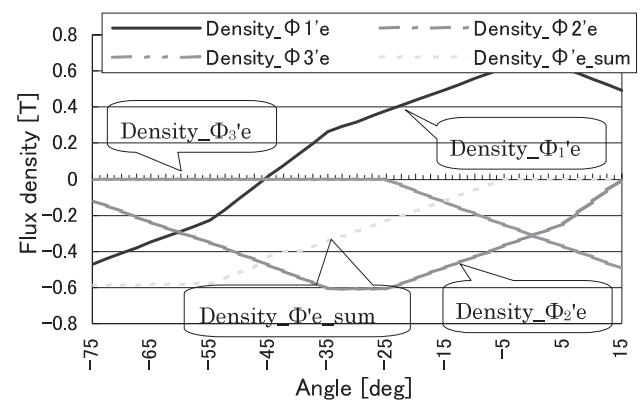

(b) Flux density of edge part at domain $(B)\left(-75^{\circ} \leq \theta \leq 15^{\circ}\right)$

図 18 領域 $(B)$ での各磁束密度の角度依存性

Fig. 18. Flux density at domain $(B)$ depending on $\theta$.

る。 $\theta \leq 15^{\circ}$ の場合, 領域 $(A)$ の磁束については [仮定 2] のモデルと同じ結果となった。領域 $(B)$ については, 例え ば図 12 の $\theta=-75^{\circ}$ に打いて領域 3-(1)，4-(1)，‥ 11(1) の磁束は同じ值となった。領域 $(B)-i-(j)$ の磁束を $\Phi_{i-(j)}^{\prime}$ と表記すると $\Phi_{3-(1)}^{\prime}=\Phi_{4-(1)}^{\prime}=\cdots=\Phi_{11-(1)}^{\prime}$ となり，そ れを $\Phi_{1}^{\prime}$ と㧍く。同様に $\Phi_{3-(2)}^{\prime}=\Phi_{4-(2)}^{\prime}=\cdots=\Phi_{11-(2)}^{\prime}$, $\Phi_{3-(3)}^{\prime}=\Phi_{4-(3)}^{\prime}=\cdots=\Phi_{11-(3)}^{\prime}$ となり, それぞれを $\Phi_{2}^{\prime}, \Phi_{3}^{\prime}$ と おく。このモデルでは領域 $(B)$ の 12-(1), (2), (3) を端部と呼 び, その磁束を $\Phi_{1 e}^{\prime}=\Phi_{12-(1)}^{\prime}, \Phi_{2 e}^{\prime}=\Phi_{12-(2)}^{\prime}, \Phi_{3 e}^{\prime}=\Phi_{12-(3)}^{\prime}$ と おく。端部における 3 相磁束の和を $\Phi_{e_{\text {_sum }}^{\prime}}^{\prime}$ とおく。すなわ ち, $\Phi_{e_{-} \text {sum }}^{\prime}=\Phi_{1 e}^{\prime}+\Phi_{2 e}^{\prime}+\Phi_{3 e}^{\prime}$ とする。また, 非端部における 3 相磁束の和を $\Phi_{\text {sum }}^{\prime}$ とおく。すなわち, $\Phi_{\text {sum }}^{\prime}=\Phi_{1}^{\prime}+\Phi_{2}^{\prime}+\Phi_{3}^{\prime}$ とする。

図 18 にパーミアンス法による解析で $-75^{\circ} \leq \theta \leq 15^{\circ}$ で の領域 $(B)$ の各磁束密度の様子を示す。 $\theta=-75^{\circ}$ の磁束密 度を見ると $\Phi_{1 e}^{\prime}$ は $\Phi_{1}^{\prime}$ と同じであるが， $\Phi_{2 e}^{\prime}$ は $\Phi_{2}^{\prime}$ より減 少しており， $\Phi_{3 e}^{\prime}$ は 0 になっている。この二つ領域の磁束 $\Phi_{2 e}^{\prime}, \Phi_{3 e}^{\prime}$ が領域 $(B)$ の全体の磁気回路に影響を与え, 非端 部の磁束 $\Phi_{1}^{\prime}, \Phi_{2}^{\prime}, \Phi_{3}^{\prime}$ が不平衡になると考えられる。この とき零相分 $\Phi_{\text {sum }}^{\prime}$ と $\Phi_{e_{-} \text {sum }}^{\prime}$ が生じる。また, $15^{\circ} \leq \theta \leq 105^{\circ}$ のときは領域 $(B)$ の端部の磁束は非端部の磁束と一致し, 領域 $(A)$ において端部の影響が発生する。この結果から端 部の磁束の変化による非端部の磁束への影響はほとんどな く, 推力の角度依存性はほとんど端部の磁束によることが 確認できた。

〈4・4〉他のアクチュエータとの比較＼cjkstart本スパイラル モータの用途を検討するため, FEM 解析の結果から他のリ ニアアクチュエータの特徵と比較した。各アクチュエータ
表 3 各アクチュエータの推力特性

Table 3. Thrust characteristics of each actuator.

\begin{tabular}{l||c|c|c|c}
\hline \hline \multicolumn{1}{c|}{ Motor } & Size $\left[\mathrm{mm}^{3}\right]$ & $\begin{array}{c}\text { Rated } \\
\text { Thrust } \\
{[\mathrm{N}]}\end{array}$ & $\begin{array}{c}\text { Thrust } \\
\text { per unit } \\
\text { Volume } \\
{\left[\mathrm{N} / \mathrm{m}^{3}\right]}\end{array}$ & $\begin{array}{c}\text { Motor } \\
\text { constant } \\
{[\mathrm{N} / \sqrt{\mathrm{W}]}}\end{array}$ \\
\hline \hline $\mathrm{SPRM}^{*_{1}}$ & $\phi 96 \times 236$ & 236 & $1.4 \times 10^{5}$ & 43.3 \\
$\mathrm{HDL}^{* 2}$ & $93 \times 74 \times 140$ & 200 & $2.1 \times 10^{5}$ & 43.2 \\
$\mathrm{LOA}^{* 3}$ & $\square 66 \times 18$ & 25 & $3.2 \times 10^{5}$ & 6.5 \\
$\mathrm{CSCLA}^{*_{4}}$ & $\square 30 \times 26.75$ & 6 & $2.5 \times 10^{5}$ & 6.4 \\
\hline \hline
\end{tabular}

*1 SPRM : Spiral motor (FEM Analysis)

*2 HDL : High Density Linear Motor (HDL-S030S)

*3 LOA : Linear Oscillatory Actuator (RM06)

*4 CSCLA : Linear Actuator with Concentratedly-placed Stationary Coils (Proto type)

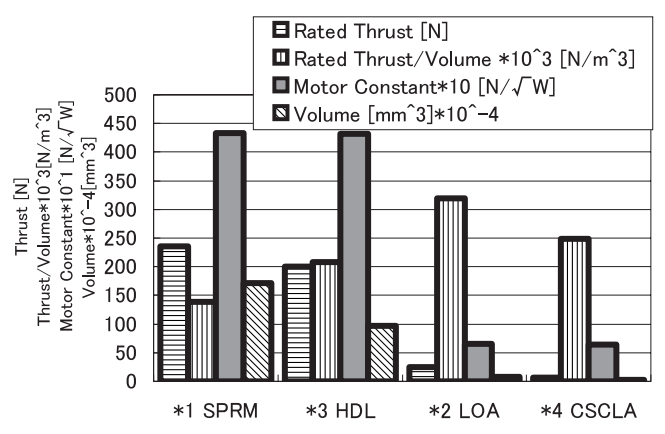

図 19 各アクチュエータの推力特性比較

Fig. 19. Thrust comparison of each actuator.

は種類によって用途も違い, また, スパイラルモータの推力 特性は FEM 解析結果であるため, 他のアクチュエータの実 験結果との直接比較することが難しいが, 本モー夕の用途 や可能性を考察するのには有効であると考えられる。比較 対象としたリニアアクチュエータはモー夕定数が大きいこ とで知られている $\mathrm{HDL}^{(7)}$, 短ストロークで小形, 高効率で あると知られているリニア振動アクチュエータ $(\mathrm{LOA})^{(12)}$, 軽量であり，銅損が少ないと知られている集中コイル型リ ニアアクチュエータ $\left(\right.$ CSCLA) ${ }^{(13)}$ とした。スパイラルモー 夕はHDLよりもストロークが短いという特徵を有するが, 本モータよりも更に短ストローク用途向きである LOA や CSCLA とも比較することでその特徴を明らかにする。比 較基準は定格推力と単位体積当りの定格推力, モ一夕定数 とした。ただし，モータの体積は可動子と固定子が重なる 電磁部のみを考慮した。また, HDL のモー夕定数は最大推 力 1000 [N] の大型の HDL モデルのモー夕定数值 ${ }^{(14)}$ から換 算した值を用いだ。

比較結果を表 3 と図 19 に示す。スパイラルモータと同 等な体積のアクチュエータはHDLであり, モー夕定数值は スパイラルモータと HDL 両者がほぼ同じ大きさになって いる。よって，スパイラルモータも高推力を得られるモー 夕となり得ると考えられる。また, LOA や CSCLA は単位 積当りの推力はスパイラルモータよりも大きいが, 定格推

\footnotetext{
† HDL-S030S のモー夕定数值は HDL モー夕のモー夕定数 $(57.6[\mathrm{~N} / \sqrt{\mathrm{W}}])$ と両者のギャップ面積の割合（1.78 倍）から文献(15) の換算式を用いて求めた。すなわち, $57.6 / \sqrt{1.78} \fallingdotseq 43.2[\mathrm{~N} / \sqrt{\mathrm{W}}]$
} 


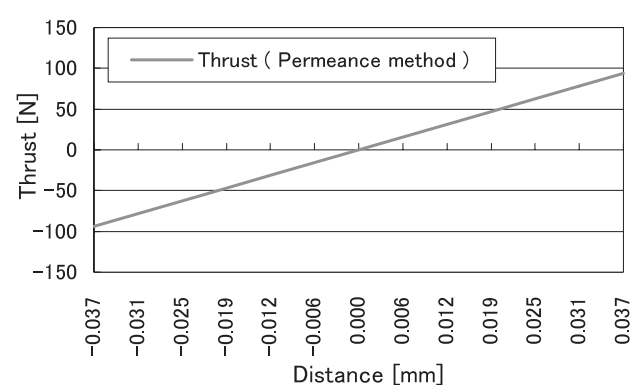

図 20 推力のギャップ変位依存性 $\left(\theta=15^{\circ}\right)$

Fig. 20. Thrust depending on $x_{q}\left(\theta=15^{\circ}\right)$.

力やモー夕定数の值は低く，より小型機器向きであるとい える。

\section{5. ギャップ変位の移動による推力平坦化}

〈5・1〉 ギャップ変位の移動による推力平坦化 $\langle 4 \cdot 3\rangle$ 節において推力が回転角 $\theta$ に依存して増減する現象につい て考察した。この推力の角度依存性を解消する方法として は固定子の層数を増し, 可動子のストローク範囲を固定子 の長さ内に制限する方法が考えられる。これはく3・2〉節で 11 層固定子モデルの解析で推力が平坦であることから確認 できる。

このほか, 可動子のギャップ変位を移動させて推力を調節 する方法が考えられる。これはギャップ面積の差が(+)側に 大きくなると領域 $(A)$ のギャップを広げるように $x_{g}$ を $(-)$ 側 に変位させて推力を調節する方法である。図 20 は〈4・1 節 のモデルを用い, 平衡角 $\theta=15^{\circ}$ においてギャップ変位 $x_{g}$ を変化させたときの推力の変化である。これは (18)の第 5 項の変位による変化を表わし, 図上には直線に見えるが, 実 際は 3 次方程式の曲線である。図 20 より $\theta>15^{\circ}$ の場合 はギャップ変位を平衡点から $(+)$ 側に微小に移動させ, 逆 に $\theta<15^{\circ}$ のときはギャップ変位を $(-)$ 側に移動させるこ とで推力変動を補償できると考えられる。図 20 を直線近 似すると, 推力平坦化のための可動子回転角によるギャッ プ平衡点の移動量は次のように表される。

$$
x_{g}=k\left(\theta-\theta_{0}\right)[\mathrm{m}]
$$

ただし， $\theta_{0}$ は平衡状態となる可動子回転角であり, $\theta_{0}=\pi / 12$ である。この場合， $k=2.37 \times 10^{-5}$ と求まる。

$\langle\mathbf{5} \cdot \mathbf{2}\rangle$ 推力平坦化の FEM 解析 FEM モデルにおい ては解析誤差を考慮して，可動子を $15^{\circ}$ 毎に $0.01[\mathrm{~mm}]$ を 移動させながら推力の変動を観察した。このときの $k$ は $k_{F E M}=3.82 \times 10^{-5}$ である。(20)のギャップ変位の移動に よる補償を行ったときの推力の FEM 解析結果を図 21(a) に示し，図 21(b) にはトルクの解析結果を示す。結果によ ると推力は予想通り平坦化されていることが分かる。しか し，トルクは変動が大きくなったことが分かる。トルクも ギャップ面積の変化に依存しているが, その傾向は推力と 異なるためであると考えられる。推力とトルクの同時平坦 化は今後の課題である。

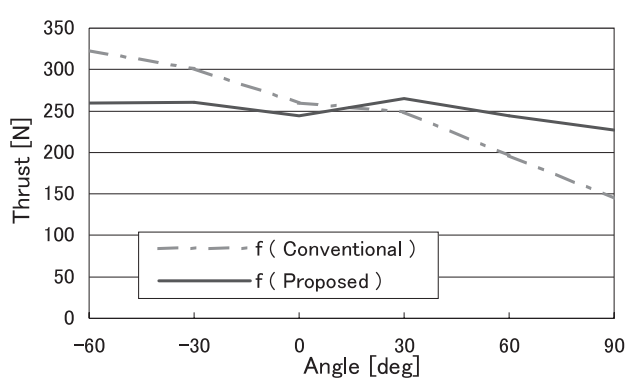

(a) Thrust depending on $\theta$

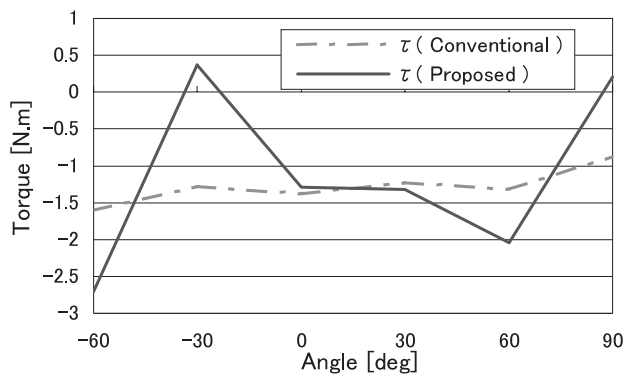

(b) Torque depending on $\theta$

図 21 各回転角でのモー夕特性

Fig. 21. Motor characteristics depending on $\theta$.

以上の結果より，スパイラルモータの推力特性はギャッ プの平衡点の微小な移動によって調節可能であることが分 かった。また，このためにギャップ変位の精密な制御が必 要であることが分かった。

\section{6. まとめ}

本論文ではスパイラル運動をモー夕単体で効率的に実現 できるスパイラルモータについて提案した。5 層固定子と 6 層可動子のスパイラルモータのモデルにおいて推力, お よび，トルク特性をパーミアンス法による解析と FEM 解 析で検討した。その結果，本モータは HDL と同等なモー 夕定数であり，高推力特性を持つ可能性があることを確認 した。また，可動子の突出量に依存して推力が増減する特 性を明らかにし, ギャップ変位の移動によって推力の平坦 化ができることを確認した。以上より，本モー夕は従来の ドライブ装置への置き換えなど，様々な応用が期待できる。 謝 辞

最後に, 本研究の一部は科学研究費補助金若手研究 A（課 題番号：15686018）を受けて行われたことを付記する。

(平成 17 年 10 月 3 日受付，平成 19 年 1 月 15 日再受付)

\section{文献}

（1）武藤高義:「アクチュエータの駆動と制御」,コロナ社, pp.43-45 (2002-1)

（2）電気学会技術報告第 911 号：「リニアドライブ技術とその応用に関 わる用語」, 電気学会, pp.5-6(2003-1)

(3) 岡田養二・長坂長彦:「サーボアクチュエータとその制御」, コロナ 社, pp.92-93 (1985-11)

（4）佐藤 寛：「次世代型 AC サーボハイブリッド油圧アクチュエータ DDV HySerpack」, 油空圧技術, Vol.41-7, pp.51-58 (2002-7)

（5）広田善晴：「環境にやさしい油空圧アクチュエータ」, 油空圧技術, Vol.42-4, pp.52-59 (2003-4) 
(6) W. Jeon, W. Tanabiki, S. Katoh, Y. Kamiya, and T. Onuki: "An Approach for Enhancing the Performance of Rotary-Linear Induction Motor", T. IEE, Vol.119-D, No.3, pp.321-326 (1999-3) (in Japanese)

田 宇鎮 · 田痱雅基 · 加藤真吾 · 紙屋雄史 · 小貫 天：「回転-リニ ア併進誘導機の性能向上に関する研究」, 電学論 D, 119, 3, pp.321-326 (1999-3)

(7) M. Karita: "High Performance Technology in Linear Motor (Special Issue on High Performance Technology in Components for Linear Drive Systems)", JSPE, Vol.61, No.3, pp.347-350 (1995-3) (in Japanese) 荻田充二：「リニアモータにおける高性能化技術（〈特集〉直動シス テム用機器にみる高性能化技術)」, 精密工学会誌, 61, 3, pp.347-340 (1995-3)

(8) S. Ueno and Y. Okada: "Characteristics of Axial Force and Rotating Torque and their Control of PM type Axial Gap Self-bearing Motor", T. IEE Japan, Vol.119-D, No.3, pp.282-290 (1999-3) (in Japanese)

上野 哲・岡田 養二：「永久磁石アキシャル形セルフベアリングモー タのアキシャル方向力とトルク特性およびその制御」, 電学論 D, 119, 3, pp.282-290 (1999-3)

(9) "Solderable enameled round copper winding wires", JCS Standard, JCS 2394:2006, p.1 (2006-3) (in Japanese)

「はんだ付け可能エナメル銅線」, 日本電線工業会, JCS 2394:2006, p.1 (2006-3)

(10) W.H. McAdams: "Heat Transmission 3rd Edition", McGraw-Hill, pp.175180 (1954)

(11) "Allowable Current of Cable for Machinery", LS Cable, LGCVol.1.1, pp.23 (2000-8) (in Korean)

(12) N. Hiroshi, F. Takashi, and M. Yosuke: "Basic Characteristics of MovingIron-Type Linear Oscillatory Actuator:「Reciprocating-Motor」”, IEE of Japan Technical Meeting Record on Linear Drives, LD-03-77, pp.7-10 (2003-9) (in Japanese)

中川 洋・福永 崇・村口洋介：「鉄心可動形 LOA『レシプロモー 夕』の諸特性」, 電気学会リニアドライブ研究会, LD-03-77, pp.7-10 (2003-9)

(13) A. Toba, K. Nakayama, and H. Mine: "Lightweight Linear Actuator with Concentratedly-placed Stationary Coils", IEEJ Trans. IA, Vol.124-D, No.6, pp.574-580 (2004-6) (in Japanese)

鳥羽章夫・中山和哉・美根宏則：「コイルを固定集中配置できる小 型軽量リニアアクチュエータ」, 電学論 D, 124, 6, pp.574-580 (2004-6)
１4）中川 洋・苅田充二：「埋込磁石式インダクタ形（HD 形）リニアモー 夕の特性改善と応用 (リニアモータの最新動向と高効率化)」, 日本 能率協会, pp.J6-3-1 10 (2002)

(15) Y. Muraguchi, H. Nakagawa, M. Maeda, K. Kato, and M. Karita: "A Linear motor suitable for driving of high frequency and this application", IEEJ Technical Meeting Record on Linear Drive, LD-99-51, pp.55-58 (1999-5) (in Japanese)

村口洋介·中川 洋 · 前田 豊 · 加藤一路 · 荻田充二 : 「高頻度運転 に適したリニアモータとその応用例」, 電学学会リニアドライブ研究 会, LD-99-51, pp.55-58 (1999-5)

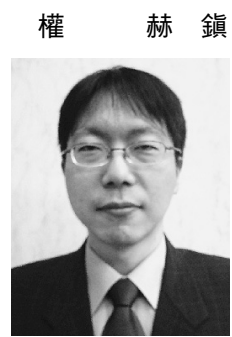

（学生員） 2000 年 2 月, 韓国国立釜慶大学大学院 メカトロニクス工学科修士課程修了。2001 年 10 月, 横浜国立大学工学府博士課程後期物理情報工 学専攻電気電子ネットワークコース入学, 現在に 至る。スパイラルモータの研究に従事。

藤 本 康 孝 (正員) 1998 年 3 月, 横浜国立大学大学院工学研

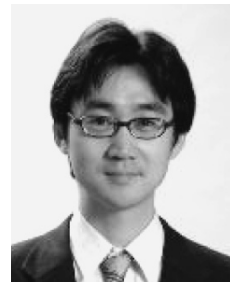
究科電子情報工学専攻博士課程修了。同年 4 月, 慶應義塾大学理工学部嘱託助手。1999 年 4 月, 横 浜国立大学工学部電子情報工学科助手。2000 年 4 月, 同講師, 2002 年 4 月, 同助教授，現在に至る。 システム工学, モーションコントロールの研究に 従事。博士 (工学)。日本ロボット学会, IEEE, INFORMS の会員。 